\title{
Effect on the fatty acid profiles of a microalgae strain (Dunaliella tertiolecta) using different lipid extraction techniques
}

\section{Efecto sobre el perfil de ácidos grasos de una cepa de microalga (Dunaliella tertiolecta) empleando técnicas diferentes de extracción de lípidos}

\author{
GÓMEZ-CORDOVA, Fidel $\dagger$, PALOMAREZ-RUIZ, Irma， SANTOS-BALLARDO, David and \\ MEJIAS-BRIZUELA, Nildia*
}

Universidad Politécnica de Sinaloa, Mexico.

ID $1^{\text {st }}$ Author: Fidel, Gómez-Cordova / ORC ID: 0000-0002-0218-7644, arXiv ID: fidel-gomez, CVU CONACYT ID: 721578

ID $1^{\text {st }}$ Coauthor: Irma, Palomares-Ruiz / ORC ID: 0000-0002-2577-1288, arXiv ID: Yomira-Palomares

ID $2^{\text {nd }}$ Coauthor: David, Santos-Ballardo / ORC ID: 0000-0001-5058-8621, Researcher ID: I-3543-2018, SNI CONACYT ID: 349858

ID $3^{\text {rd }}$ Coauthor: Nildia, Mejias-Brizuela / ORC ID: 0000-0003-2973-473X, Researcher ID: I-5834-2018, SNI CONACYT ID: 253092

DOI: $10.35429 /$ EJE.2020.12.7.15.22

Received January 10, 2020; Accepted June 30, 2020

\begin{abstract}
Biodiesel is subject of research because it is less polluting when used in pure form or mixed with petroleum diesel. Microalgae are now a material new in research for mass production of biodiesel, so the techniques used for cell growth, biomass extraction and lipid extraction influence the profile of fatty acids susceptible to transesterification and consequently the quality of biofuel. This work shows the effect on the fatty acid profile of a Dunaliella tertiolecta strain using two lipid extraction techniques. For this, the culture was carried out in the medium F/2, the recovery of the biomass was carried out by sedimentation-flocculation with $\mathrm{NaOH}$ and once dry it was subjected to extraction with solvent by Soxhlet and by ultrasound to obtain lipids under the methodology by Bligh \& Dyer. The fatty acids were analyzed by gas chromatography and the profile is made up of saturated-monounsaturated-polyunsaturated fatty acids and shows differences regarding the presence-absence and dry weight content. This represents a contribution to analyze the effect on physicochemical parameters established in Mexican regulations regarding the quality of biodiesel and to determine the potential of the microalgae strain for such production.
\end{abstract}

Microalgae, Fatty acids, Biodiesel

\begin{abstract}
Resumen
El biodiésel es objeto de investigación debido a que es menos contaminate si se utiliza en forma pura o mezclado con diesel de petróleo. Las microalgas, son actualmente un insumo en investigación para producción masiva de biodiésel, por lo que las técnicas empleadas para crecimiento celular, extracción de biomasa y lípidos influyen en el perfil de ácidos grasos susceptible de transesterificación y por consecuencia en la calidad del biocombustible. Este trabajo muestra el efecto sobre el perfil de ácidos grasos de una cepa de Dunaliella tertiolecta empleando dos técnicas de extracción de lípidos. Para ello el cultivo se llevó a cabo en el medio F/2, la recuperación de la biomasa se realizó por sedimentaciónfloculación con $\mathrm{NaOH}$ y ya seca se sometió a la extracción con disolvente por Soxhlet y por ultrasonido para obtención de lípidos bajo la metodología de Bligh y Dyer. Los ácidos grasos se analizaron por cromatografía de gases y el perfil se compone de ácidos grasos saturados-monoinsaturadospoliinsaturados y muestra diferencias respecto a la presenciaausencia y contenido en peso seco de ellos. Esto representa un aporte para analizar el efecto sobre parámetros fisicoquímicos establecidos en la normativa mexicana respecto a la calidad del biodiésel y para determinar el potencial de la cepa de microalga para tal producción.
\end{abstract}

Microalga, Ácidos grasos, Biodiésel

Citation: GÓMEZ-CORDOVA, Fidel, PALOMAREZ-RUIZ, Irma, SANTOS-BALLARDO, David and MEJIASBRIZUELA, Nildia. Effect on the fatty acid profiles of a microalgae strain (Dunaliella tertiolecta) using different lipid extraction techniques. ECORFAN Journal-Ecuador. 2020. 7-12:15-22.

*Correspondence to Autor (E-mail: nmejias@upsin.edu.mx)

$\dagger$ Researcher contributing as first author. 


\section{Introduction}

Diesel is a petroleum product composed of a mixture of saturated (unbranched) and aromatic hydrocarbons subjected to hydro sulfurization to reduce the sulfur content that it naturally possesses. In Mexico, through NOM-016-CRE2016, two diesel names are produced and sold, the maximum of $500 \mathrm{ppm}$ of sulfur (equivalent to $500 \mathrm{mg}$ of sulfur $/ \mathrm{Kg}$ diesel or $0.05 \%$ by weight) for use in sector agricultural-marine and industrial diesel for use in direct fire combustion, and the minimum of $15 \mathrm{ppm}$ of sulfur $(0.0015 \%$ by weight) known as ultra-low sulfur diesel (ULSD) only for use in transport sector in the Metropolitan Zone of the Valley of Mexico, Guadalajara, Monterrey, the Northern Border Zone and imported diesel.

Both denominations generate atmospheric emissions of sulfur oxides and particulate matter as a consequence of combustion processes in each of the engines in which they are used, also causing negative effects on soil, water and human health, a challenging problem to be solved in this century to achieve the sustainable local development worldwide.

This problematic requires research in the area of bioenergy to produce alternative biofuels from varied inputs, easily acquired or extracted, that can be used alone or mixed with petroleum products, technologies for conversion by sustainable processes that give added value to by-products and finally thus reducing energy dependence on imports.

Biodiesel is promising because it has a favorable energy content compared to petroleum diesel, in its pure form it is highly biodegradable, free of aromatic compounds, non-toxic and with sulfur content $(<0.0020 \%)$ (Pinzi et al., 2009) very similar to ULSD and well below $500 \mathrm{ppm}$ diesel. For mixing, it can be under any proportion, B20 being the most commercialized (B5 the minimum). Its emissions have a lower risk of cancer in the population compared to fossil diesel (Manuale, 2011).
The materials to achieve a quality biodiesel production is a key factor and object of research, ranging from vegetable oils from crops and residuals, animal fats (the traditional ones) that contribute to reduce contamination in bodies of water by direct discharge of these, to more promising inputs (due to their short-term and permanent production) based on a variety of species of some genera of microalgae that produce high lipid content for the transesterification of the fatty acids (FA) that constitute them.

However, some biodiesel parameters such as oxidation stability and low temperature properties are favored or affected by the presence-absence, high-low content of a SFA, MUFA an PUFA, which determines the potential of the input for produce quality biodiesel and ultimately reduce the number of raw materials in practice. This creates the need to also analyze lipid extraction techniques for the study of the FA profile and from there make the decision-making adjusted to energy and economic expenses.

This work shows the FA profile in a strain of the microalgae Dunaliella tertiolecta and the variations that exist employed two techniques used for the extraction of lipids, one very fast and efficient such as ultrasound and the other very classic such as Soxhlet, previous recovery of the biomass under an affordable flocculation methodology.

The sections of this article are methodology, results, and analysis regarding the effect of biodiesel properties in a hypothetical production by transesterification of $\mathrm{AG}$ and the conclusions that are derived.

\section{Methodology}

The culture of the Dunaliella tertiolecta strain was carried out for 20 days in the cell growth medium of Guillard \& Ryther (1962) known as $\mathrm{F} / 2$ prepared in a saline medium ( $\mathrm{NaCl}$ solution). It began with the transfer of the microalgae to a sterile Erlenmeyer flask with $120 \mathrm{~mL}$ of F 2 medium. Once the exponential phase began and in order to achieve a high quantity and concentration of biomass, reactors were inoculated (with an average initial cell concentration of $4 \times 10^{5}$ cells $\left.\mathrm{mL}^{-1}\right)$ by volumetric transfer of medium F/2 (Coutteau, 2013) until a final volume of $16 \mathrm{~L}$ in $19 \mathrm{~L}$ reactors.

GÓMEZ-CORDOVA, Fidel, PALOMAREZ-RUIZ, Irma, SANTOS-BALLARDO, David and MEJIAS-BRIZUELA, Nildia. Effect on the fatty acid profiles of a microalgae strain (Dunaliella tertiolecta) using different lipid extraction techniques. ECORFAN Journal-Ecuador. 2020 
For this, the cell density was determined per day and tripled in aliquots of $1 \mathrm{~mL}$ extracted from the culture by counting through a microscope in a double bright line Neubauer Chamber.

The extraction of the dispersed algal biomass in the final volume of work is affected by the dilutions that are made. For effective recovery, a flocculation-sedimentation methodology was adapted, induced by a change in $\mathrm{pH}$ of the culture medium from 7.8 to 11.0 , adding $1 \mathrm{M} \mathrm{NaOH}$ and a rest time of $24 \mathrm{~h}$ (Beevi, et al. 2016; Rojo-Cebreros et al. 2016). Subsequently, centrifugation (5 min, $5000 \mathrm{rpm}$ ) and lyophilization $\left(-50^{\circ} \mathrm{C}, 1.3 \mathrm{~Pa}, 72 \mathrm{~h}\right)$ were performed to dehydrate it completely (Chen, et al., 2011).

The recovery of the fat content present in the dry powder algal biomass was carried out by solvent extraction using two techniques: the conventional Soxhlet solid-liquid extraction method and the solid-liquid extraction method by ultrasonic waves. In both methodologies, the chloroform/methanol mixture was used as a solvent in a $2: 1$ ratio adapted to the process proposed by Bligh \& Dyer (1959) commonly used for the extraction of neutral and polar lipids for energy purposes. In all trials, three replicates were performed.

The Soxhlet extraction was carried out in an average time of $4 \mathrm{~h}$ using a $500 \mathrm{~mL}$ extractor equipment (composed of a thermomagnetic plate, solvent volumetric balloon, cellulose filter where the biomass was placed, extractor, condenser) coupled to an external cooling system $\left(10 \mathrm{~L}\right.$ of water $\left.4 \pm 1{ }^{\circ} \mathrm{C}\right)$. Once the process was finished, the sample was placed in a separatory funnel and methanol/distilled water (100/180 mL) was added for the separation of the phases, $24 \mathrm{~h}$ later the lower phase (biomass/lipids-chloroform) was extracted and carried to a rotary evaporator (thermal bath 40 ${ }^{\circ} \mathrm{C}, 60 \mathrm{rpm}, 10 \mathrm{~min}$ ) to remove solvents. Finally, the lipid extract was stored in amber flasks at 5 ${ }^{\circ} \mathrm{C}$.
The ultrasound extraction began with the suspension of the biomass in the 2:1 chloroform/methanol mixture and it was centrifuged (200 rpm, $15 \mathrm{~min}$ ) and then placed in an ultrasonic bath (Branson 1510 power 70 W) at a fixed frequency of $40 \mathrm{KHz}$ for $20 \mathrm{~min}$ and achieve the electronic excitation that generates the intramolecular vibrations. It was then centrifuged (150 rpm, $15 \mathrm{~min})$ for the separation of biomass/liquid phase with final adjustment of chloroform/methanol/water at a ratio $2: 2: 1.8$. It was transferred to a decantation balloon and proceeded in the same way as Soxhlet (extraction of the biomass/lipidchloroform phase, evaporation of the solvent and protection of the fatty extract (González, 2011; King, 2014; Soto-León, et al., 2014).

The lipid productivity $\left(\mathrm{mg} \mathrm{L}^{-1} \mathrm{~d}^{-1}\right)$ was calculated using equation 1 , that relates the biomass productivity (biomass produced during the entire exponential growth phase expressed in $\mathrm{g} \mathrm{L}^{-1} \mathrm{~d}^{-1}$ ) and the total content percentage of lipids quantified by weight difference of biomass before and after extraction (Song, et al., 2013).

$L P=B P \times L$

The determination of the fatty acids in the lipid extracts was carried out by injecting 1.0 $\mu \mathrm{L}$ of sample into an Agilent ${ }^{\circledR} 7820 \mathrm{~A}$ gas chromatograph coupled to an FID (flame ionization) detector and a DB 5Ht column. The column-oven temperatures were programmed from $50{ }^{\circ} \mathrm{C}$ to $180{ }^{\circ} \mathrm{C}$ at a rate of $10{ }^{\circ} \mathrm{C} \mathrm{min}{ }^{-1}$, then to $320{ }^{\circ} \mathrm{C}$ at a rate of $4{ }^{\circ} \mathrm{C} \mathrm{min}^{-1}$. The injector temperature was $300{ }^{\circ} \mathrm{C}$ and that of the FID detector $320^{\circ} \mathrm{C}$.

The qualitative analysis of the fatty methyl esters that make up the sample (obtained by chemical conversion of the lipid extract of each treatment) was carried out by measuring the retention times and their comparison with reference standards (37 components FAME brand SupelcoTM Mixture C4-C24). The quantitative analysis consisted in the integration of the total area under the peaks shown in the chromatogram assuming that the fatty methyl esters were totally separated. The analyses were carried out in triplicate and the results are presented as a normalized percentage average by weight of each component. 


\section{Results}

The kinetic behavior of the Dunaliella tertiolecta strain in the $\mathrm{F} / 2$ culture medium is shown in Graphic 1 as an average of the daily cell count in the working replicas and represents a characteristic sigmoid curve of the growth of microorganisms. The exponential growth phase begins slowly the first $72 \mathrm{~h}$ and from there it increases progressively until day 18 where we obtained $2.10 \pm 0.12 \times 10^{6}$ cells $\mathrm{mL}^{-1}$ are reached, considered the maximum cell concentration that declines from day 19 as a result of the competition of microorganisms by nutrients in the middle giving way to the death phase from day 20 .

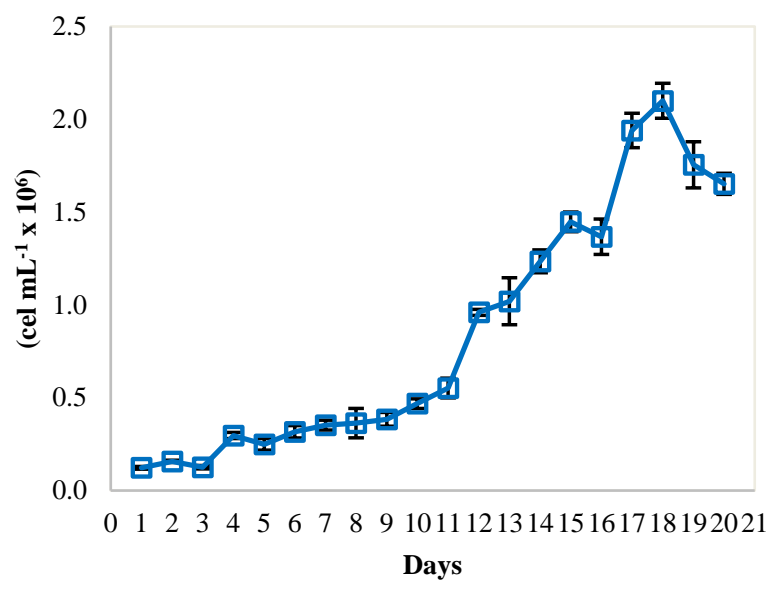

Graphic 1 Cell growth kinetics of Dunaliella tertiolecta Source: self-made

The specific cell growth rate $(\mu)$ was 0.21 $\pm 0.02 d^{-1}$ for a doubling time $(t d)$ of the concentration of the microorganisms of $3.34 \pm$ $0.29 d$, calculated from the averages obtained by the daily counting method. The results obtained are within the values reported by some authors using the same culture medium. For example, for cell density Neto et al. (2012) reported a similar behaviour of 22 days, reaching a maximum of $0.81 \times 10^{6}$ cel $\mathrm{mL}^{-1}$ on day 18 , lower than that reported, while, Gárate (2020) under analogous laboratory conditions reached between days 12 14 a maximum of $3.39 \times 10^{6}$ cells $\mathrm{mL}^{-1}$, greater than that reported here. Regarding the growth rate and doubling time, El Arrousi et al in 2015 reported $\mu$ equal to $0.34 d^{-1}$ and $t d$ of $2 d$, Félix (2017) reported $\mu$ of $0.27 d^{-1}$ and a $t d$ of $2.59 d$.
It should be noted that all microalgal growth will always present slight or marked differences with respect to another, not only due to modifications to the nutrient medium based mainly on the use of a natural saline medium and an elaborated saline medium and limitation of nutrients, but also by the parameters physical elements that complement it, such as light intensity, photoperiod, temperature, agitation, etc. (Chen, et al., 2011; Félix, 2017).

The flocculation efficiency for the recovery of the biomass generated in the crops using $1 \mathrm{M} \mathrm{NaOH}$ per $\mathrm{pH}$ change was $99 \%$, which states that it is a simple, affordable and effective methodology, since this chemical agent acts as a powerful destabilizer of the electrostatic charges present in the cell and from the change in acidity due to the increase in the $\mathrm{pH}$ of the culture medium, the cells agglomerate and form large flocs, sedimentation at the end of $24 \mathrm{~h}$. The results are similar to those reported by RojoCebreros, et al. (2016) that achieved an efficiency of $94.9 \%$ of biomass recovery in a Nannochloropsis sp strain for aquaculture purposes using $\mathrm{NaOH} 0.5 \mathrm{eq} \mathrm{L}^{-1}$ in less than $1 \mathrm{~h}$, Unmalyma, et al. (2016) through a study for biomass extraction in Chlorococcum $s p$ determined that $\mathrm{NaOH}$ was the most effective agent for flocculation with $94 \%$ compared to $\mathrm{Al}_{2} \mathrm{SO}_{4}$, which was $87 \%$.

The extraction of accumulated lipids in Dunaliella tertioelcta using Soxhlet/Bligh \& Dyer ultrasound allowed to determine the percentage content of dry base lipids and the average lipid productivity per day. Thus, at the end of the crops an average biomass productivity of $23.12 \mathrm{mg} \mathrm{L}^{-1} \mathrm{~d}^{-1}$ was obtained, a percentage content of lipids extracted by Soxhlet-Bligh \& Dyer of $26.9 \pm 0.8 \%$ and an average lipid productivity of $6.22 \mathrm{mg} \mathrm{L}^{-1} \mathrm{~d}^{-1}$, while, by ultrasound-Bligh \& Dyer, a higher lipid content of $33.5 \pm 1.1 \%$ and a productivity of $7,813 \mathrm{mg}$ $\mathrm{L}^{-1} \mathrm{~d}^{-1}$ was obtained. These results are within the range reported in the bibliography for this species of microalgae (16.7 to $71 \%$ ) (Takagi, et al., 2006; Sydney et al., 2010 and El Arroussi, et $a l ., 2015)$ and for many marine microalgae (Mata, et al., 2010). 
Again, the lipid content will be affected by the same factors that influence microbiological growth already mentioned (different strains of a species of microalgae, nutrients, temperature, light and the variations that may occur in these) as well as the extraction techniques and the solvents they use.

Under this thematic, Araujo, et al. (2013) analyzed the lipid extraction efficiency in biomass obtained from Chlorella vulgaris by different solvent methodologies (among them Folch, Bligh and Dyer \& Soxhlet) applying ultrasound and determined that the Bligh \& Dyer methodology presented the highest extraction efficiency $(52.5 \%)$ and the Soxhlet extraction was the one with the lowest lipid recovery (1.8 $\%$, attributing the differences to the characteristics of the cell wall and its behavior (greater or lesser affinity) against solvents or a mixture of them and the respective proportion that is used, as well as the power of the equipment, temperature, time, washes.

Suarsini and Subandi (2012) in biomass of Chlorella vulgaris and Spirogya sp. analyzed the efficiency of three lipid extraction methods (Soxhlet, maceration and ultrasound) as a function of the time used and using n-hexane as a solvent. They established the following: ultrasound $(2.33 \mathrm{~h}, 1.77 \%)>$ maceration $(8 \mathrm{~h}$, $1.03 \%)>$ Soxhlet $(18 \mathrm{~h}, 1.58 \%)$ and concluded that ultrasound is an efficient technique for lipid extraction because it uses less extraction time, with very good performance and generates less waste compared to the other two.

The fatty acids (or fatty acid methyl esters or FAME) obtained from the lipids extracted from the Dunaliella tertiolecta strain by the proposed techniques and in comparison, with the standard reference standards are shown in Graphic 2.

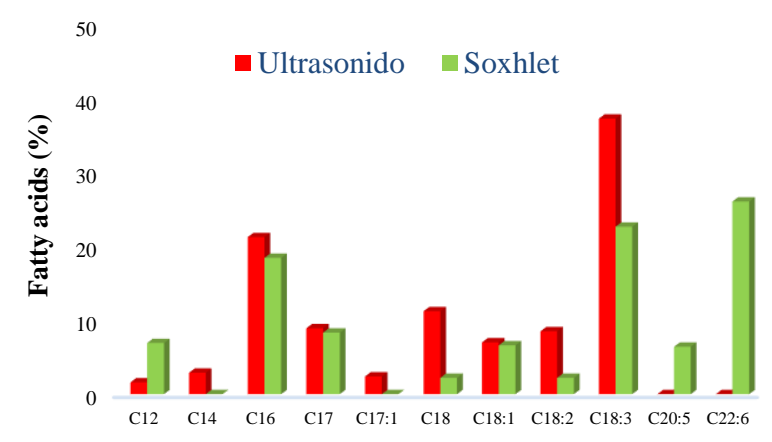

Graphic 2 Fatty acids in a Dunaliella tertiolecta strain using two extraction techniques Source: Self-made

ISSN-On line: 1390-9959

ECORFAN $^{\circledR}$ All rights reserved.
We identified 9 FA distributed as SFA (C12-C18), MUFA (C17:1-C18:1) and PUFA (C18:2-C22:6) whose percentage content is summarized in Table 1.

\begin{tabular}{|c|c|c|}
\hline \multirow[t]{2}{*}{ FAME } & \multicolumn{2}{|c|}{ Relative Percentage (\%) } \\
\hline & Ultrasound & Soxhlet \\
\hline SFA & 45.8 & 35.8 \\
\hline MUFA & 9.0 & 6.8 \\
\hline PUFA & 45.2 & 57.4 \\
\hline
\end{tabular}

Table 1 Composition of fatty acids present in a Dunaliella tertiolecta strain

Source: Self-made

According to what was obtained, lipid extraction techniques influenced the FAME profile, since Soxhlet yielded 2 new FAME and others did not (for example, C14), in some contents they are slight differences and in others, very marked. However, the profile is in accordance with that reported in the bibliography for each technique and the same nutrient medium $(F / 2)$ since generally these coincide in a greater presence of FAME, in compounds from $\mathrm{C} 16$ to $\mathrm{C} 18$ and $\mathrm{C} 18: 3$ (Chen, et al., 2011; Tang, et al. 2011; El Arroussi, et al., 2015) and coincides with other marine species of the same or different genus (Tanzi, et al., 2013; Tadeo-Sánchez, et al., 2014).

The ultrasound extraction efficiency is attributed to mechanical and cavitation processes. Cavitation contributes to the breakdown of the cell wall of the microalgae by the vibrations that are generated, which allows greater and easy penetration of the solvent mixture and by the electrostatic interactions that occur between the two, lipids are quickly released, mechanical processes they help better agitation of the solvent which increases the surface area of contact (Spinella, et al. 2016).

Taking into account only the FAME with the highest percentage content, for the SFA, palmitic acid (C16) regardless of the extraction technique, the same happens for oleic acid (C18: 1 ), in the MUFA, while, for the PUFA, by ultrasound the highest percentage was linolenic acid (C18:3) and by Soxhlet, it was Cis4,7,13,16,19-docosahexaenoic acid (C22:6).
GÓMEZ-CORDOVA, Fidel, PALOMAREZ-RUIZ, Irma, SANTOS-BALLARDO, David and MEJIAS-BRIZUELA, Nildia. Effect on the fatty acid profiles of a microalgae strain (Dunaliella tertiolecta) using different lipid extraction techniques. ECORFAN Journal-Ecuador. 2020 
Regarding the production of biodiesel adjusted to Mexican or international regulations, the physicochemical parameters such as oxidative stability, flow properties at low temperatures, viscosity, number of cetanes are the most interesting and depend on the FAME present in the raw material of origin.

The ideal is long-chain FAME with low unsaturation number, that is, SFA and MUFA such as C14 (myristic), C16 (palmitic) and C18: 1 (oleic) respectively since they give the biodiesel oxidative stability, high cetane number and lubricity, low viscosity and toxicity, being palmitic acid the one that particularly confers the highest number of cetanes and consequently greater stability to oxidation. However, a high content of SFA compromises the flow properties of biodiesel at low temperatures. Oleic acid is the main methyl ester of biodiesel that allows high lubricity and ignition and low viscosity and toxicity (Pinzi, et al., 2009; Tadeo-Sánchez, et al., 2014).

The contribution of PUFA (linoleic and linolenic) is that they favor the operation of biodiesel at low temperatures since they present a lower melting point, which provides greater fluidity of the biodiesel in the engine. The problem is their susceptibility to oxidation, which would affect the storage of biodiesel for a long time, which can be corrected with the addition of oxidizing compounds that can be obtained in the biodiesel production chain or with protection in environments with low light and drafts. air. (Moreira, 2012, Tejeda, et al. 2015).

Arias, et al., (2013) proposed that to guarantee quality biodiesel, the convenient thing would be a mixture of FAME produced by different types of microalgae, since the objective is to be able to develop a sustainable, viable and feasible process in the economic and competitive energy terms. with fossil fuels.

\section{Thanks}

To CONACYT for a scholarship granted to the first author for postgraduate, to PRODEP for support to CA of Energy Engineering, to Biotechnology Engineering UPSIN for loan of equipment and materials.

\section{Conclusions}

Sodium hydroxide turned out to be an excellent flocculant for the extraction of microalgal biomass due to the time it was used and the percentage of recovery that was obtained.

Cell disruption methods employing solvent extraction such as Bligh and Dyer allow pure lipid extracts even when they are of low dry base content.

The ultrasound extraction was efficient due to the time used $(20 \mathrm{~min})$ and the FAME profile obtained. Soxhlet extraction is one of the most used methods for the extraction of fat content in microalgae despite a negative balance in terms of working time and energy consumption, however, it is a reference method with which other methods of extraction. In this investigation, it was carried out in $4 \mathrm{~h}$ and yielded a different FAME profile.

The FAME profile together with the lipid productivity and biomass productivity are key factors for decision-making regarding a pilot or mass production of biodiesel.

The FAME profile was compensated by a lower concentration of SFA and a higher proportion of MUFA and PUFA, which coincides with investigations regarding the same species in this work, other species, other microalgae genera and even plant crops and animal fats. The profile obtained contains acceptable percentages of the FAME suitable for transesterification.

We recommend to carry out the production and characterize the biofuel based on the existing Mexican regulations and determine the influence of the FAME obtained, mainly linolenic acid on oxidation stability as it is the characteristic with the greatest impact on the use

Finally, it is also recommended from an economic viability point of view to implement crops with photoperiods since electricity consumption is one of the parameters that negatively impact the process and therefore the long-awaited sustainability, as well as determining the viability for a scale. pilot in environmental conditions with use of solar energy in the region. 


\section{References}

Araujo, G., Matos, L., Fernandes, J., Cartaxo S., Gonçalves L., Fernandes F., Farias, W. (2013). Extraction of lipids from microalgae by ultrasound application: Prospection of the optimal extraction method. Ultrason Sonochem, 20(1) 95-99.

Beevi, S., Mathew, A. Pandey, A. Sukumaran, R. (2016). Harvesting of microalgal biomass: Efficient method flocculation through $\mathrm{pH}$ modulation. Bioresources Technology. 213, 216-221.

Blight, E., Dyer W. (1959). A rapid method of total lipid extraction and purification. Canadian J. of Biochemistry and Physiology, 37 (8), 911917.

Coutteau, P. (2013). Algal production in MicroAlgae. Food and Agriculture Organization.

Chen, M., Tang, H., Ma H., Holland, T., Simon, K., Salley, S. (2011). Effect of nutrients on growth and lipid accumulation in the green algae Dunaliella tertiolecta. Bioresource Technology, 102 (2), 1649-1655.

Diario Oficial de la Federación. (12/05/2016). Norma Oficial Mexicana NOM-016-CRE-2016, Especificaciones de calidad de los petrolíferos.

El Arroussi, H., Benhima, R., Bennis, I., El Mernissi, N., Wahby, I. (2015). Improvement of the potential of Dunaliella tertiolecta as a source of biodiesel by auxin treatment coupled to salt stress. Renewable energy. 77, 15-19.

Félix, A. L. (2017). Formulación de una bebida funcional a base de biomasa residual de la microalga Dunaliella tertiolecta [Tesis de Maestría, Universidad Autónoma de Sinaloa].

Gárate, A. (2020). Analisis del potencial de la microalga Dunaliella tertiolecta para la obtención de bioporoductos bajo el concepto de biorrefinería [Tesis de Maestría, Universidad Politécnica de Sinaloa].

Guillard, R., Ryther, J. (1962). Studies of marine planktonic diatoms. I. Cyclotella nana Hustedt, and Detonula confervacea (cleve) Gran. Canad. J. Microbiol, 8 (2), 229-239.
González, Á., Galindo, L., González, S., Peralta, Y., Kafarov, V. (2011). Adaptación del método Bligh \& Dyer a la extracción de lípidos de microalgas colombianas para la producción de biodiésel de tercera generación Rev. Especializada en Ingeniería de Procesos en Alimentos y Biomateriales, 6, 25-34.

King, P. (2014). The use of ultrasound on the extraction of microalgal lipids. [Tesis de Maestría, Coventry University].

Manuale, D. (2011). Obtención de biodiésel en condiciones supercríticas [Tesis de Maestría, Universidad Nacional del Litoral].

Mata, M., Martins, A. Caetano, N. (2010). Microalgae for biodiesel production and other applications: A review. Renew sustain. Energy Rev., 141, 245-251.

Moreira, E. (2012). Principales características de las materias primas utilizadas en la producción de biodiesel: la influencia del contenido y la concentración de los ácidos grasos. Ingenium Rev. Fac. Ing. 13(25), 53-61.

Pinzi, S., García, I., López-Giménez, F., Luque, M., Dorado G., Dorado, M. (2009). The ideal vegetable oil-based biodiesel composition: A review of social, economic and technical implications. Energy Fuels, 23(5), 2325-2341.

Rojo-Cebreros, A., Morales-Plascencia, M., Ibarra-Castro, L., Martínez-Brown, J., MedinaJasso, M. (2016). Floculación de Nannochloropsis sp. inducida por hidróxido de sodio: eficiencia de floculación, efecto sobre la viabilidad microalgal y su uso como alimento para rotíferos. Lat. Am. J. Aquat. Res. 44(4), 662-670.

Song, M., Pei, H., Hu, W., Ma, G. (2013). Evaluation of potential of 10 microalgal strains for biodiesel production. Bioresource Technology, 141, 245-251.

Soto-León, S., Zazueta-Patrón, E., Piña-Valdez, P., Nieves-Soto, M., Reyes-Moreno, C., Contreras-Andrade, I. (2014). Extracción de lípidos de Tretaselmis suecica: Proceso asistido por ultrasonido y solventes. Rev. Mexicana de Ing. Química, 13 (3), 723-737. 
Suarsini, E., Subandi, S. (2012). The use ultrasonic to increase the efficiency of oil extraction for microalgae indigenous isolates from Pond Gresik, East Java. International Journal of Renewable Energy Resources, 2, 6973.

Sydney, E., Sturn, W., De Carvalho, JC, Thomaz-Soccol, V., Larroche, C., Pandey, A., Soccol, C. R. (2010). Potential carbon dioxide fixation by industrially important microalgae. Bioresource Technology, 101 (15), 5892-5896.

Tadeo-Sánchez, L., Puentes-Cárdenas, I., Flores-Ortiz, C., Sánchez-García, D., PinedaCamacho, G., Cristiani-Urbina, E. (2014). Producción de biodiésel por Nannochloropsis $s p$. bajo diferentes condiciones ambientales. Rev. Cubana de Química, XXVI (3), 276-298.

Takagi, M., Karseno, Yoshida, T. (2006). Effect of salt concentration on intracellular accumulation of pipids and triacylglyceride in marine microalgae Dunaliella cells. J. of Bioscience and Bioengineering, 101 (3), 223226.

Ummalyma S., Matthew, A., Pandey, A. Sukumaran, K. (2016). Harvesting of microalgal biomass: Efficient method flocculation through pH modulation. Bioresource Technology. 213, 216-221. 